\title{
DAKWAH DAN PERDEBATAN SOAL PLURALISME
}

\author{
Erwin Jusuf Thaib, Andries Kango \\ Fakultas Ushuluddin dan Dakwah \\ IAIN Sultan Amai Gorontalo \\ Jl. Gelatik No. 1 Kota Gorontalo 96119 \\ erwinjthaib@iaingorontalo.ac.id
}

\begin{abstract}
:
Da'wah is basically a social activity that allows people to meet with various social backgrounds in it. Because of its nature as a social activity, plurality becomes a necessity in da'wah. Nevertheless, pluralism as a reality sometimes becomes a problem in society. This article aims to describe the problem between da'wah and pluralism with the subject of the meaning of pluralism, its reality in the history of Islamic da'wah, and the attitude that must be developed in responding to it. The study showed that pluralism is generally interpreted as diversity in various aspects of life, including religion, which is believed to originate from one source even though this causes controversy. Historically Islam recognized the reality of religious pluralism. This fact shows that in Islam differences of belief are not obstacles to managing social life together as a form of acceptance of religious pluralism. Some attitudes that must be developed to be able to accept the reality of religious pluralism in daily life include interfaith dialogue, conducting "passing over" and "coming back" activities, or making efforts to increase multiculturalism insight to all elements of society. All of this can be done through the Islamic da'wah, with its various approaches, has become a massive Islamic religious social movement and is able to reach all aspects of Islamic society life.
\end{abstract}

Keywords: da'wah, pluralism, religion 
Komunike, Volume XII, No. 1 Juni 2020

\begin{abstract}
Abstrak
Dakwah pada dasarnya adalah sebuah aktivitas sosial yang memungkinkan bertemunya orang dengan berbagai latar sosial di dalamnya. Karena sifatnya sebagai sebuah aktivitas sosial, maka pluralitas menjadi sebuah keniscayaan dalam dakwah. Meskipun demikian, pluralisme sebagai sebuah kenyataan terkadang menjadi masalah dalam masyarakat. Artikel ini bertujuan untuk menggambarkan permasalahan antara dakwah dan pluralisme dengan pokok bahasan tentang pluralisme, realitasnya dalam sejarah dakwah Islam, serta sikap yang harus dikembangkan dalam menyikapinya. Kajian dalam artikel ini menemukan bahwa pluralisme secara umum dimaknai sebagai keragaman dalam berbagai aspek kehidupan termasuk agama yang diyakini bersumber dari satu sumber meskipun hal ini menimbulkan kontroversi. Secara historis Islam mengakui realitas pluralisme agama. Fakta ini memperlihatkan bahwa dalam Islam perbedaan keyakinan bukanlah halangan untuk mengelola kehidupan sosial bersama-sama sebagai satu bentuk penerimaan terhadap pluralisme agama. Beberapa sikap yang harus dikembangkan untuk dapat menerima realitas pluralisme agama dalam kehidupan sehari-hari antara lain melalui dialog antar agama, melakukan aktivitas "passing over" dan " coming back", atau melakukan upaya peningkatan wawasan multikulturalisme kepada seluruh elemen masyarakat. Semua hal ini bisa dilakukan melalui medium dakwah Islamiyah yang dengan beragam pendekatannya, telah menjadi gerakan sosial keagamaan Islam yang masif dan mampu menjangkau seluruh aspek kehidupan masyarakat Islam.
\end{abstract}

Kata kunci: dakwah, pluralisme, agama. 


\section{PENDAHULUAN}

Upaya penyebaran agama pada dasarnya merupakan satu bagian yang pasti ada dalam kehidupan umat beragama. Dalam ajaran agama Islam, hal ini disebut dengan dakwah, hal ini merupakan suatu kewajiban yang dibebankan oleh agama kepada setiap pemeluknya, setidaknya kewajiban berdakwah ini dilakukan kepada diri sendiri dan keluarga serta kerabat dekat. Dengan demikian, maka dakwah dalam agama Islam mempunyai basis personal yang cukup kuat dalam pribadi setiap pemeluknya.

Dakwah adalah seruan atau ajakan kepada keinsafan, atau bisa juga disebut sebagai upaya mengubah suatu situasi kepada situasi yang lebih baik dan sempurna, baik terhadap pribadi maupun masyarakat. Perwujudan dakwah bukan sekadar usaha peningkatan pemahaman keagamaan dalam tingkah laku dan pandangan hidup saja, tetapi menuju sasaran yang lebih luas lagi. ${ }^{1}$

Dalam doktrin Islam, setiap penganutnya diperintahkan untuk memperjuangkan dan menyebarluaskan kebenaran, kapan dan di manapun dia berada. Semangat untuk memperjuangkan, mempertahankan dan kemudian menyebarluaskan kebenaran inilah yang kemudian mengkristal dalam dakwah. Karena semangat inilah, maka tidaklah mengherankan bila dalam sepanjang sejarahnya, agama Islam hampir tidak pernah terpisah dengan dakwah. Dan karena gerakan dakwah, maka agama Islam kemudian hadir di hampir setiap penjuru dunia dewasa ini. Islam telah eksis mulai dari Semenanjung Arabia, Palestina, Suriah, Mesopotamia, Persia, India, Asia Tengah, Malaysia, Indonesia, dan Filipina di bagian Timur, serta Mesir, Afrika Utara, Spanyol, dan Afrika Tengah di bagian Barat dan kemudian ke Asia Kecil

${ }^{1}$ H.M. Quraish Shihab Shihab, Membumikan Al-Qur'an (Bandung: Mizan, 1997) hlm. 194 
dan dari sanalah menyebar ke Eropa Timur sampai di Austria. ${ }^{2}$

$$
\text { Gambaran di atas }
$$

menunjukkan betapa eratnya relasi antara Islam dan gerakan dakwah.

Bahkan bisa dikatakan bahwa dakwah dalam Islam merupakan keberadaan agama Islam itu sendiri, sehingga menelusuri sejarah dakwah dalam Islam merupakan penelusuran terhadap keberadaan Islam itu sendiri sebab konsep Islam adalah agama dakwah baik teori maupun praktek. Dan Nabi Muhammad saw sebagai pemimpin agama dalam Islam merupakan seorang dai dan dalam kiprah dakwahnya telah berhasil menarik masuk orang-orang yang awalnya kafir menjadi pemeluk Islam yang taat. ${ }^{3}$

Hakekat dakwah adalah kegiatan untuk melakukan transformasi keagamaan baik secara horisontal maupun secara vertikal.
Transformasi keagamaan secara horisontal adalah terjadinya konversi dari pemeluk agama yang bukan Islam menjadi pemeluk Islam. Adapun secara vertikal adalah dari pemahaman dan pengamalan Islam yang dangkal menjadi pemeluk Islam yang memahami dan mengamalkan serta menghayati Islam secara mendalam. ${ }^{4}$

Dengan demikian tugas dakwah secara esensial sesungguhnya adalah tugas setiap pribadi muslim dalam rangka memelihara eksistensi Islam, bahkan mengembangkan Islam sebagai suatu anutan atau pedoman hidup dan kehidupan manusia di dunia ini. Oleh sebab itu para dai sebagai pelanjut Rasulullah saw tidak boleh bersikap pasif. Mereka harus menyambut tantangan-tantangan di hadapannya dengan perencanaan dakwah yang baik. ${ }^{5}$

${ }^{4}$ M. Masykur Amin, Dakwah Islam dan Pesan Moral. (Yogyakarta: Al-Amin Press, 1997) hlm. 89

${ }^{5}$ Jalaluddin Rakhmat, Islam Aktual. (Bandung: Mizan, 1998) hlm. 75 Da'wah Islam. (Jakarta: Widjaya. 1981) hlm. 4-5

${ }^{2}$ Harun Nasution, Islam Ditinjau Dari Berbagai Aspeknya. (Jakarta: UI Press, 1985) hlm.32

\section{${ }^{3}$ Thomas W. Arnold, Sejarah}




\begin{abstract}
Konsekwensi logis dari gagasan-gagasan di atas adalah tersebarnya pesan-pesan dakwah melalui berbagai saluran yang mungkin digunakan sebagai media dakwah. Secara tradisional, pesanpesan dakwah disampaikan secara billisa $>n$, artinya pesan-pesan dakwah disampaikan dengan bahasa-bahasa verbal seperti ceramah, khotbah, pengajian-pengajian dan lain sebagainya. Selain itu, pesan-pesan dakwah bisa juga mengalir lewat saluran bil-ha>l, yaitu penyampaian dakwah melalui bahasa-bahasa non verbal seperti perilaku, sikap, akhlaq yang mulia, bahkan juga melalui saluran perkawinan, perdagangan, dan lain sebagainya, sebagaimana yang telah dicontohkan oleh Rasulullah saw.
\end{abstract}

Dewasa ini terdapat beberapa isu besar yang begitu mendapat perhatian yang sangat besar di seluruh pelosok dunia yaitu masalah

\footnotetext{
${ }^{6}$ Muhammad Adib dan Nur Qomari, "Arus Baru Politik Islam: Pluralisme, Kontestasi, dan Demokratisasi, Maqashid, Jurnal Hukum Islam Volume 1, no. 2, 2018, hlm. 18-33

${ }^{7}$ Rusman Widodo, Editorial Jurnal HAM Komnas HAM. Volume 11, 2014, hlm. v-xvi. Lihat juga Najid Jauhar,
}

demokrasi $^{6}$, hak asasi manusia $(\mathrm{HAM})^{7}$, masalah konservasi lingkungan dan pluralisme khususnya yang berkaitan dengan kehidupan beragama. $^{8}$ Upaya demokratisasi digalakkan di seluruh dunia untuk memastikan bahwa seluruh elemen masyarakat dunia memiliki hak dan kewajiban yang sama untuk berpartisipasi di pentas politik dan pemerintahan, karena dalam realitas yang sering terlihat hal tersebut hanya dikuasai dan bisa diakses oleh sekelompok golongan elit dalam suatu komunitas masyarakat. Selanjutnya, masalah hak asasi manusia juga menjadi salah satu isu besar dunia didorong oleh fakta maraknya pelanggaran hak asasi manusia dalam berbagai bentuk di hampir seluruh belahan dunia. Adapun masalah yang ketiga yaitu menyangkut konservasi lingkungan. Hal ini didorong oleh begitu banyak fakta tentang degradasi kualitas lingkungan karena

"Islam, Demokrasi, dan HAM, Sebuah Benturan Filosofis dan Teologis”. Jurnal Ilmu Sosial dan Ilmu Politik Volume 11, no. 1, 2007, hlm. 31-61

${ }^{8}$ M. Dian Hikmawan, "Pluralisme Demokrasi Politik di Indonesia”. Journal of Governance Volume 2, no. 2, 2017, hlm. 223247 
Komunike, Volume XII, No. 1 Juni 2020

berbagai aktivitas yang cenderung tidak ramah lingkungan. Sedangkan isu yang keempat adalah berkaitan dengan masalah pluralisme keagamaan. Hal ini berkaitan dengan fakta bahwa terdapat beragam keyakinan yang dianut oleh milyaran manusia di muka bumi ini.

Berbicara tentang masalah pluralisme keagamaan pada umumnya orang akan mengaitkannya dengan berbagai silang pendapat yang berkaitan dengan masalah ini. Pluralisme menjadi perdebatan panjang dari kalangan pendukung dan penentangnya. Dalam konteks Indonesia, perdebatan ini diperparah oleh lahirnya fatwa haram dari Majelis Ulama Indonesia (MUI) yang mengharamkan paham paham sekularisme, pluralisme, dan liberalisme. ${ }^{9}$ Fatwa ini tentu saja mendapat kritikan dari berbagai kalangan yang berseberangan dengan MUI, salah satunya berasal dari

\footnotetext{
${ }^{9}$ Hijrah S, MUI, Kontroversi Fatwa MUI, dan Buku Himpunan Fatwa MUI, dalam http://www.erlangga.co.id/agama/7066mui-kontroversi-fatwa-mui-dan-bukuhimpunan-fatwa-mui.html
}

kalangan Jaringan Islam Liberal (JIL) yang berpandangan bahwa MUI telah salah dalam menafsirkan paham sekularisme, pluralisme dan liberalisme. $^{10}$

Dalam silang pendapat tentang pluralisme keagamaan inilah, dakwah Islamiyah sebagai salah satu media penerangan agama dalam masyarakat harus ikut masuk ke dalam ranah perdebatan ini dan sebisa mungkin memberi solusi terbaik dari sisi agama sebagai nilai rujukan dan dari sisi agama sebagai penganut agama Islam yang menyerap ilmu pengetahuan agamanya dari aktivitas dakwah. Bagaimana sesungguhnya pluralisme keagamaan menjadi kontroversi yang berkepanjangan di Indonesia, serta bagaimana dakwah masuk dan memberi solusi terhadap perdebatan ini, akan dijadikan pembahasan utama dalam artikel ini.

\footnotetext{
${ }^{10}$ Hamdiah A. Latif, "Mengkritisi Jaringan Islam Liberal (JIL): Antara Spirit Revivalisme, Liberalisme, dan Bahaya Sekularisme. Jurnal Ilmiah ISLAM FUTURA Volume 10, no.2, 2011, hlm. 50-64
} 
Pembahasan dalam artikel ini bertujuan untuk menggambarkan bagaimana relasi dakwah Islamiyah dengan kontroversi seputar paham pluralisme agama sebagai bagian dari khazanah pengetahuan Islam secara umum. Hal ini menjadi penting untuk menjadikan setiap pemeluk agama Islam mempunyai pemahaman yang dalam tentang dasar-dasar keyakinannya sambil tetap bisa hidup berdampingan secara harmonis dengan penganut keyakinan berbeda dalam kehidupannya.

\section{METODE PENELITIAN}

Kajian dalam artikel ini yang mebahas tentang permasalahan dakwah dan persoalan pluralism dilakukan dengan menggunakan metode penelitian pustaka (library research). Riset yang berbasis pada kepustakaan akan berupaya memanfaatkan sumber-sumber Pustaka untuk perolehan data penelitian. ${ }^{11}$ Meskipun berangkat dari realitas sosial yang ada dalam masyarakat, namun penelitian

11 Mestika Zed, Metode Penelitian Kepustakaan (Jakarta: Yayasan Obor Indonesia, 2008) hlm. 1-2 kepustakaan membatasi analisisnya pada analisis kepustakaan.

Dengan pendekatan metodologi kepustakaan, maka dalam artikel ini data-data yang berkaitan dengan permasalahan dakwah dalam relasinya dengan permasalahan pluralisme dikaji dengan mencari data yang berkaitan dengan permasalahan ini. Sumber-sumber pustakan yang membahas tentang dakwah dan pluralism, baik yang terjadi di zaman Nabi Muhammad saw hingga di era modern digunakan sebagai rujukan utama.

Dalam penelitian kepustakaan setidaknya terdapat tiga tehnik pengumpulan data pokok berupa pengumpulan bahan-bahan pustaka, penelusuran informasi kepustakaan, dan pengorganisasian serta penyajian data-data. ${ }^{12}$ Berdasarkan hal ini, maka analisis permasalahan dalam artikel ini diawali dengan penelusuran sumber kepustakaan, pemilahan informasi yang relevan, dan dilakukan pengorganisasian data dan analisis yang berkaitan dengan dengan pokok

${ }^{12}$ James Dananjaja, Metode Penelitian Kepustakaan, Jurnal Antropologi Indonesia Nomor 52, 1997, hlm. 83 
Komunike, Volume XII, No. 1 Juni 2020

permasalahan dan ditarik sebuah kesimpulan dari pembahasan sebagai temuan dalam penelitian ini.

\section{Pluralisme dan kontroversi tentangnya.}

Istilah pluralisme seringkali diartikan sebagai suatu keadaan masyarakat yang majemuk terutama yang bersangkutan dengan masalah sosial dan politik. Dalam kaitannya dengan kebudayaan, maka istilah ini dipahami sebagai kebudayaan yang berbeda-beda dalam suatu masyarakat. ${ }^{13}$ Istilah ini berasal dari kata dasar bahasa Inggris, plural, yang berarti jamak ${ }^{14}$, suatu kata yang merujuk pada makna keragaman atau jumlah yang banyak. Dalam terminologi bahasa Arab kontemporer, kata pluralisme disebut dengan istilah Al-Ta'addudiyah ( التعد ية ) yang mengandung makna banyaknya bilangan $^{15}$, yang menunjukkan makna keragaman. Pengertian-pengertian di atas

\footnotetext{
${ }^{13}$ Departemen Pendidikan dan Kebudayaan. Kamus Besar Bahasa Indonesia. (Jakarta: PN Balai Pustaka. 2002) hlm. 761

${ }^{14}$ John M. Echols dan Hassan Shadily, Kamus Inggris Indonesia (Jakarta: PT Gramedia Pustaka Utama, 1996) hlm. 435
}

masihlah sebatas pengertian dari aspek etimologis. Pengertian ini masih sangat mendasar, karena untuk memahami makna pluralisme harus melihat berbagai aspek pemahaman di luar aspek kebahasaan itu sendiri. Menurut Abou El-Fadhl ${ }^{16}$, pluralisme adalah kesediaan untuk menjunjung pluralitas yakni kesediaan untuk menerima kenyataan bahwa masyarakat hidup dalam realitas yang berbeda dan bersedia menerima perbedaan sebagai sebuah kenyataan yang tak terhindarkan.

Paham tentang pluralisme sejatinya bukanlah topik perdebatan yang lahir dari dunia Islam. Menurut Anis Malik Taha, paham ini lahir dari hasil pertentangan pemikiran dan konflik yang terjadi antara gereja dengan umat Kristen yang ingin keluar dari kekangan gereja yang bersifat otoriter. Hal seperti dicontohkan dengan ditangkapnya Galileo Galilei yang pandangannya

\footnotetext{
${ }^{15}$ Ahmad Warson Munawwir, Kamus Al-Munawwir Arab-Indonesia (Surabaya: Pustaka Progresif, 1997) hlm. 904

${ }^{16}$ Abid Rohmanu, "Pluralisme, Demokrasi dan Keadilan Sosial Dalam Konsepsi Fiqih Humanistik Abou El-Fadl" ISLAMICA Volume 4, no.1, 2009, hlm. 17-34
} 
tentang bumi bertolak belakang dengan pandangan pihak gereja.Ketika sains selalu dibenturkan dengan doktrin-doktrin gereja yang dipaksakan, hal ini menimbulkan reaksi yang sangat keras dari para ilmuwan Kristen Barat sehingga memilih untuk menolak otoritas gereja (bahkan agama) dalam mematok benar salahnya penemuan-penemuan sains mereka. ${ }^{17}$ Dari dulu hingga sekarang, bahkan sampai masa-masa akan datang; persoalan pluralisme agama terutama antara Ahli Kitab (Yahudi dan Nashara) di satu pihak, dan Islam dipihak lain, selalu menggelitik banyak pihak. Teori teologi pluralis yang belakangan kian marak di Indonesia, merupakan salah satu indikatornya. Demikian pula dengan ungkapan-ungkapan: "Tiga Agama (Yahudi, Nasrani, dan Islam) Satu Tuhan, "Semua Agama Adalah Sama," ${ }^{18}$ dan lain sebagainya adalah jargon-jargon yang menunjukkan

\footnotetext{
${ }^{17}$ Anis Malik Taha, Tren Pluralisme Agama, Tinjauan Kritis. (Jakarta: Gema Insani Press, 2005) hlm. 16

${ }^{18}$ Muhammad Amin Suma, Pluralisme Agama Menurut Al-Qur'an, Telaah Aqidah dan Syari'ah. (Jakarta: Pustaka Firdaus, 2001) hlm. 3
}

adanya kesadaran tentang pluralisme agama, sekaligus juga jargon-jargon yang senantiasa menuai kontroversi.

Paham pluralisme dalam pandangan Nurcholish Madjid sebagaimana dikutip oleh Budhy Munawar Rachman ${ }^{19}$ dikatakan bahwa pluralisme tidak dapat dipahami hanya dengan mengatakan bahwa masyarakat itu majemuk, beraneka ragam, terdiri dari berbagai suku dan agama, yang justru hanya menggambarkan kesan fragmentasi dan bukan pluralisme. Pluralisme harus dipahami sebagai "pertalian sejati kebinekaan dalam ikatanikatan keadaban". Bahkan pluralisme adalah suatu keharusan bagi keselamatan umat manusia, antara lain melalui mekanisme pengawasan dan pengimbangan yang dihasilkannya. Dalam kitab suci justru disebutkan bahwa Allah menciptakan mekanisme pengawasan dan pengimbangan antara sesama manusia guna memelihara keutuhan

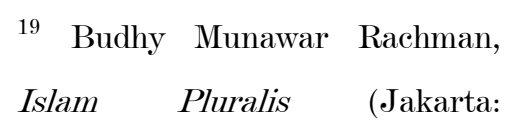

Paramadina, 2001) hlm. 31 
Komunike, Volume XII, No. 1 Juni 2020

bumi, dan merupakan salah satu wujud kemurahan Tuhan yang melimpah kepada umat manusia.

Apa yang diungkapkan oleh Nurcholish Madjid di atas menunjukkan bahwa pluralisme tidak bisa dipahami dari aspek sosiologis, antropologis atau kultural semata. Karena pandangan seperti ini justru menegaskan adanya realitas fragmentatif atau adanya pecahanpecahan karena adanya sekat-sekat yang hadir dalam ranah sosio kultural masyarakat. Hal ini justru jauh dari gambaran tentang pluralisme. Menurutnya pluralisme itu adalah sebuah ikatan kesatuan untuk membentuk peradaban. Pluralisme justru harus dipahami dari aspek teologis karena memuat jaminan keselamatan kehidupan manusia, karena manusia tidak akan berbuat semena-mena karena adanya kesadaran akan adanya pengawasan sehingga menghasilkan sebuah sikap yang seimbang. Nilai keseimbangan itu sendiri adalah sebuah nilai yang ideal dalam rangka membentuk suatu kehidupan masyarakat yang ideal.

Paham pluralisme dalam perspektif Frithjof Schuon memandang bahwa pada dasarnya tidaklah penting perbedaan antar agama, karena kalau dilihat dari segi transenden dimana yang ada hanyalah kesatuan, suatu hal yang merupakan jantung dari agamaagama. Menurut pandangan ini, perbedaan yang penting bukanlah antara agama-agama, tetapi antara orang-orang dalam setiap agama. Mereka yang bisa memahami apa yang ada di atas garis - yaitu segi "kesatuan transenden agama-agama" - dapat didentifikasikan sebagai seorang esoteris. Mereka itu - yang berasal dari berbagai maca agama sadar bahwa mereka secara ultim (titik puncak) ada dalam satu kesatuan dengan penganut agamaagama lain, karena seluruhnya dari dan akan kembali kepada Yang Ilahi. ${ }^{20}$

Pendapat Schuon di atas diperkuat oleh pandangan Ibnu

${ }^{20}$ Budhy Munawar Rachman, Islam

Pluralis, hlm. 51-52 
Taymiyyah (661-728 H) yang secara tegas menyatakan bahwa asal usul agama itu pada dasarnya adalah satu yaitu Islam, walaupun syari'atnya kemudian berbeda-beda. Ibnu Taymiyah mendasarkan kesimpulannya pada ini kepada hadis Nabi Muhammad saw yang menyatakan:

\section{إنَّاَ مَعَاثِرَ الَالَنْبِيَاء دِينُنَا وَاحِدُ الأنبياء إخوة لعلات}

Terjemahnya:

"Sesungguhnya kami adalah keluarga besar para nabi; agama kami satu, dan para nabi adalah bersaudara seayah (walaupun ibunya berbeda-beda). Lebih lanjut Ibnu Taymiyyah mengatakan bahwa agama para Nabi adalah satu yakni menyembah Allah yang tidak ada sekutu bagi-Nya, yaitu Dzat yang selalu disembah pada setiap waktu menurut aturan yang diperintahkan waktu itu. Dan yang demikian itu adalah din al-Isla>m. Kemudian secara berangsur-angsur melalui alna $>$ sikh wa al-mansu $>k h$, ajaran itu

${ }^{21}$ Al-Dimasyqi, Taqyuddin Abu Al-Abbas Ahmad bin Abd Al-Halim bin Abd Al-Salam bin Abdullah bin Abi Al-Qasim bin Muhammad Ibn Taymiyyah Al-Harrani Al- mengalami perubahan dan

pembaruan menuju ke arah penyempurnaan seperti layaknya satu syari'at. Dengan demikian maka agama Islam yang dengannya Allah mengutus Muhammad saw, adalah agama yang satu. ${ }^{21}$

Berbagai pendapat di atas baik itu yang diungkapkan oleh Nurcholish Madjid, Frithjof Schuon, maupun Ibnu Taymiyyah memperlihatkan bahwa pluralisme cenderung kepada sebuah paham tentang Wahdat al-Adya>n atau kesatuan agama-agama, di mana dalam satu titik kulminatif agamaagam itu bertemu. Agama bersatu secara esensial, terlepas dari keragaman syariat yang menyertai masing-masing agama.

Pandangan di atas di satu sisi dapat dilihat sebagai wujud pemutlakan keberadaan Tuhan sebagai sumber segala sesuatu di dunia ini termasuk juga agama. Sehingga pandangan ini bisa menjadi sebuah penegasan akan posisi Allah

Hanbali, Al-Fatawa Al-Kubra Li-Ibn Taymiyyah. (t.tp: Dar Al-Kutub Al-Ilmiyyah, 1408-1987) hlm. 450 
swt sebagai Dzat yang Maha Kuasa secara mutlak. Meskipun demikian pandangan-pandangan seperti ini juga melahirkan problem yang menyatakan bahwa kelompokkelompok yang berpandangan seperti ini adalah kelompok yang menjadikan agama itu relatif karena menghilangkan batas-batas klaim kebenaran antara satu dengan yang lainnya, bahkan berujung pada pandangan bahwa semua agama adalah sama saja. Problem-problem seperti inilah yang menjadi pokok perdebatan tentang pluralisme agama, antara yang mendukungnya dan yang menolaknya, khususnya di Indonesia.

Kontroversi tentang pluralisme terutama dipicu oleh lahirnya fatwa Majelis Ulama Indonesia (MUI) pada tahun 2005, yang mengeluarkan fatwa pelarangan kepada masyarakat Muslim untuk menganut paham sekularisme, pluralisme, dan liberalisme. Bagi kalangan yang memperjuangkan isme-isme tersebut percaya bahwa ketiganya merupakan

\footnotetext{
${ }^{22}$ Hijrah S, MUI, Kontroversi Fatwa MUI, dan Buku Himpunan Fatwa MUI, dalam
}

pilar demokrasi yang jika ditiadakan akan meruntuhkan bangunan demokrasi di Indonesia. Namun MUI mempunyai pandangan lain mengenai tiga isme tersebut. Menurut MUI sekularisme dianggap membahayakan akidah dan syari'at Islam karena mengajarkan relativisme agama, penafian dan pengingkaran adanya hukum Allah (syariat) serta menggantikannya dengan hukumhukum hasil pemikiran akal semata. Adapun liberalisme mendorong pengikutnya untuk menafsirkan agama secara bebas dan tanpa kaidah penuntun. Sedangkan pluralisme disesatkan karena dianggap mengajarkan sinkretisme agama atau penyamaan kebenaran semua agama. $^{22}$

Secara spesifik menyangkut paham pluralisme, fatwa MUI tertanggal 28 Juli 2005 menyatakan sebagai berikut:

"Pluralisme adalah suatu paham yang mengajarkan bahwa semua agama adalah sama dan karenanya kebenaran setiap agama

http://www.erlangga.co.id/agama/7066-muikontroversi-fatwa-mui-dan-buku-himpunanfatwa-mui.html 
adalah relatif; oleh sebab itu, setiap pemeluk agama tidak boleh mengklaim bahwa hanya agamanya saja yang benar sedangkan agama yang lain salah. Pluralisme juga mengajarkan bahwa semua pemeluk agama akan masuk dan hidup dan berdampingan di surga".23

Banyak kalangan mengkritik keras terhadap fatwa MUI yang melarang paham sekularisme, pluralisme, dan liberalisme. Menurut mereka, MUI tidak memahami secara tepat definisi tersebut. Jika kita lihat definisi Liberalisme menurut MUI dan membandingkannya dengan definisi liberalisme sesungguhnya, memang ada kesalah-mengertian akan definisi liberalisme menurut MUI. Liberalisme adalah doktrin politik yang menjunjung tinggi nilainilai individu, yang menghendaki peminimalisiran campur tangan pemerintah dan mengedepankan asas rasionalitas, persamaan dan kebebasan. $^{24}$ Ketiga asas ini

\begin{tabular}{lcc}
\hline${ }^{23}$ "Pluralisme". 2019. & Wikipedia \\
Indonesia & Ensiklopedia & Bebas. \\
http://id.wikipedia.org/wiki/Pluralisme
\end{tabular}

24 Hamid Fahmy Zarkasyi, "Liberalisasi Pemikiran Islam: Gerakan merupakan sendi demokrasi, yang merupakan sistem pemerintahan negeri ini dan tentunya sama sekali tidak melanggar nilai-nilai ajaran Islam. Adapun yang yang dimaksudkan untuk mendefinisakan liberalisme versi MUI di atas adalah definisi rasionalime yang mengedepankan akal dan kebebasan. Apakah salah kalau umat Islam mengedepankan akal ? Kalau mau menelusuri khasanah intelektual klasik, pemikir-pemikir Islam klasik juga banyak yang menganut rasionalisme. Sebut saja Ibnu Khaldun, Ibnu Rusyd, kaum Mu'tazilah, dan banyak pemikir Islam lainnya. Dalam pendefinisian pluralisme pun MUI mendapat kritik yang keras. Pluralisme diartikan oleh MUI sebagai paham menyamakan semua agama atau sinkretisme. Adapun bagi para penganut dan pejuang paham ini, pluralisme merupakan paham yang mesti dianut masyarakat di Indonesia yang

Bersama Missionaris, Orientalis, dan Kolonialis." Jurnal TSAQAFAH Volume 5, no.1, 2011, hlm. 1-28 
Komunike, Volume XII, No. 1 Juni 2020

merupakan bangsa yang majemuk atau plural. Pluralisme merupakan paham yang menekankan kepada masyarakat untuk saling menghormati ideologi, agama dan pandangan yang dianut kelompok di luar kelompoknya. Hal ini selaras dengan falsafah Pancasila, Bhineka Tunggal ika. Juga, sama sekali tidak melanggar nilai-nilai ajaran Islam. ${ }^{25}$

Silang pendapat tentang paham pluralisme di Indonesia memang merupakan persoalan yang sulit untuk dipertemukan, karena masing-masing pihak berpegang pada pendapat masing-masing, lengkap dengan sumber-sumber rujukan yang diyakini kebenarannya oleh setiap kelompok. Situasi seperti ini tentu saja membutuhkan jalan tengah agar umat Islam tidak terjebak ke dalam kebingungan akan hal ini. salah satu pihak yang mungkin bisa memberi jalan tengah atas perdebatan ini adalah dakwah Islamiyah yang dengan pendekatan-pendekatan yang

\footnotetext{
${ }^{25} \mathrm{Hijrah}$ S, MUI, Kontroversi Fatwa MUI, dan Buku Himpunan Fatwa MUI, dalam http://www.erlangga.co.id/agama/7066-mui-
}

dimilikinya diharapkan mampu memberi solusi atas persoalan ini.

Pluralisme dalam realitas sejarah dan dakwah Islam.

Islam adalah agama yang
besar karena jasa dari gerakan
dakwah Islamiyah. Nabi Muhammad
saw sebagai juru dakwah pertama
memulai gerakan dakwahnya melawan kerasnya suku Quraisy di Mekah. Dan kondisi ini menyebabkan gerakan dakwah Nabi di Mekah kurang berhasil bila dilihat dari jumlah pengikut. Akan tetapi jumlah pengikut yang sedikit inilah yang justru menunjang keberhasilan dakwah Nabi pada tahapan selanjutnya terutama setelah beliau memutuskan untuk hijrah ke Kota Yatsrib

Keputusan Nabi Muhammad saw untuk hijrah ke Kota Yatsrib didorong oleh kenyataan bahwa Kota Mekah relatif tidak kondusif lagi untuk berdakwah karena ancaman yang tidak pernah putus dari kaum Quraisy. Situasi ini bahkan sudah

kontroversi-fatwa-mui-dan-buku-himpunanfatwa-mui.html 
secara langsung mengancam jiwa Nabi Muhammad saw. Proses hijrah itu sendiri dilakukan dengan susah payah karena melalui jalan-jalan yang tidak biasa dilalui oleh kafilah dagang untuk menghindari penyergapan oleh pihak Quraisy. ${ }^{26}$

Dalam khazanah Islam, pluralisme hukum bukan hal baru, ini terkandung dalam konsep rahmatan lil 'a>lami>n, yang di dukung oleh sejumlah ayat Al-Qur'an dan praktek Nabi Muhammad saw. Catatan sejarah membuktikan keragaman budaya, suku, kasta sosial masyarakat Arab mendapat pengakuan dalam tradisi keislaman, meskipun masih terdapat perbedaan cara pandang dari suku-suku atau kabilah-kabilah Arab, namun perbedaan tersebut dapat disatukan dalam perjanjian Bersama. ${ }^{27}$

$$
\text { Yatsrib yang kemudian }
$$

diganti namanya menjadi Madinatun Nabi (Kota Nabi) memberikan babak baru dalam perjuangan Nabi menegakkan Islam. Sikap

\footnotetext{
${ }^{26}$ Muhammad Husain Haikal, Sejarah Hidup Muhammad (Jakarta: Litera Antar Nusa, 1989) hlm. 19

${ }^{27}$ Dedy Sumardi, "Islam, Pluralisme Hukum dan Refleksi Masyakat
}

masyarakat Yatsrib yang sangat ramah serta kondisi geografisnya yang subur membuat karakter masyarakat menjadi ramah dan lemah lembut. Di samping itu pula, Nabi Muhammad saw sudah begitu terkenal di kota ini akibat gerakan dakwah yang dibawa oleh para mubalig Islam pada masa itu di antaranya Mus'ab bin Umair. Langkah awal dalam upaya dakwahnya di Madinah, maka Nabi membangun masjid dan tempat tinggal untuk kaum Muhajirin. Masjid ini kelak akan menjadi pusat dakwah dan pusat pemerintahan negara Madinah yang terbentuk kemudian.

Untuk menguatkan barisan kaum Muslimin di Madinah, maka Nabi Muhammad saw berusaha untuk mempersaudarakan antara kaum Muhajirin dan Anshar. Nabi sendiri bersaudara dengan Ali bin Abi Thalib, Hamzah pamannya bersaudara dengan Zaid bin Haritsah, Abu Bakar dengan Kharija bin Zaid, Umar bin

Homogen". Asy-Syir'ah, Jurnal Suari'ah dan Hukum Volume 50, no. 2, 2016, hlm. 481504

Erwin Jusuf Thaib, Andries Kango 55 
Komunike, Volume XII, No. 1 Juni 2020

Khattab dengah Itbah bin Malik AlKhazraji, dan masih banyak lagi. Oleh Nabi mereka itu dikemukakan sebagai saudara sedarah senasab. Dengan persaudaraan itu, maka hubungan kaum Muslimin semakin kukuh adanya. $^{28}$

Akan tetapi, suatu langkah politik yang luar biasa dilakukan oleh Nabi Muhammad saw yang membawa pengaruh positif terhadap gerakan dakwahnya yaitu upaya mewujudkan Madinah yang bersatu dan terdiri atas komponen Muhajirin, Anshar, serta golongan Yahudi dan Nasrani sebagai dua agama besar yang sudah lebih dahulu eksis di kota Madinah. Persatuan ini ditegakkan di atas landasan kebebasan dan persekutuan yang erat. Fakta ini juga menggambarkan bahwa dalam menjalankan gerakan dakwahnya, Nabi tidaklah memaksakan ajaran Islam kepada pemeluk agama lain. Nabi saw sudah memberikan contoh tentang bagaimana dakwah Islamiyah tetap bisa tegak dengan menjunjung tinggi realitas pluralisme agama

\footnotetext{
${ }^{28}$ Muhammad Husain Haikal Sejarah Hidup Muhammad, hlm. 197
}

dalam kehidupan masyarakat yang berbeda keyakinan.

Untuk memperkuat landasan persatuan masyarakat multi etnis dan multi religi di Madinah, Nabi saw merumuskan suatu landasan konstitusional bernama Piagam Madinah di mana salah satu isinya adalah memberikan jaminan kebebasan kepada semua keyakinan untuk menjalankan ibadahnya, kebebasan menyatakan pendapat, jaminan atas keselamatan harta benda, larangan orang melakukan kejahatan, serta adanya kewajiban bersama untuk menjaga keamanan dan ketertiban kota Madinah. ${ }^{29}$

Gerakan dakwah Nabi Muhammad saw di Kota Madinah tampaknya sudah mulai bercapur dengan gerakan politik. Di kota ini, nabi telah mulai berupaya membentuk suatu tatanan masyarakat yang adil, yang terdiri atas berbagai komponen baik itu dari golongan Muslim maupun non Muslim. Di dalam sejarah, terbukti Nabi berhasil membentuk negara

\footnotetext{
${ }^{29}$ Muhammad Husain Haikal, Sejarah Hidup Muhammad, hlm. 205
} 
Islam Madinah yang secara langsung telah ikut berperan besar dalam menunjang keberhasilan dakwahnya dengan tetap menghargai pluralitas masyarakat yang berbeda keyakinan. Hal ini membuktikan bahwa dalam sejarah Islam tampak adanya relasi yang amat kuat antara dakwah Islamiyah dengan toleransi antar umat beragama yang telah diperankan langsung oleh juru dakwah utama, Nabi Muhammad saw.

\section{Sikap umat beragama terhadap} realitas pluralisme dalam kehidupan.

Pluralisme agama - kalaupun itu bisa diterima dan diaplikasikan dalam kehidupan — tidak bisa hanya diwujudkan dalam tataran teoritis saja, tetapi harus diupayakan pada tataran praktisnya. Oleh karena itu dibutuhkan sikap-sikap yang harus ditumbuhkan untuk mengadaptasikannya dalam kehidupan sehari-hari. Salah satu sikap yang sudah umum dikembangkan dewasa ini adalah

\footnotetext{
${ }^{30}$ Franz Magnis Suseno, Pluralisme Keagamaan: Sebuah Tanggung Jawab Bersama, dalam Muhammad Wahyuni Nafis dkk (editor), Kontekstualisasi
}

sikap toleransi. Meskipun toleransi adalah sesuatu hal yang kelihatannya mudah dipahami dan dipraktekkan, akan tetapi tidak mudah mencari bagaimana sesungguhnya modelmodel toleransi antar umat beragama itu, baik dari segi teori maupun prakteknya. Prof. Franz Magnis Suseno $^{30} \quad$ (1995) mengemukakan beberapa model toleransi yang bisa diterapkan dalam kehidupan seharihari yakni:

1. Dari Toleransi ke Non Diskriminasi Sikap dasar yang memungkinkan beberapa agama hidup berdampingan adalah toleransi. Pada prinsipnya semua agama besar menjalankan prinsip toleransi. Mereka mebiarkan umat-umat beragama lain hidup berkembang, meskipun dalam kenyataannya tidak memperoleh kesetaraan penuh. Hal itu biasanya berlaku pada agamaagama lokal, apakah itu agama yang lebih tua atau itu adalah agamaagama dari wilayah yang direbut. Lebih sulit toleransi itu dilakukan

Ajaran Islam (Jakarta: IPHI dan Yayasan Wakaf Paramadina, 1995) hlm. 467-471 
Komunike, Volume XII, No. 1 Juni 2020

terhadap agama-agama yang datang kemudian, yang sering dianggap sebagai ancaman.

Di zaman modern ini kesadaran itu dirumuskan dalam prinsip kebebasan beragama. Prinsip ini sering menimbulkan salah paham sebagai pengakuan hak orang untuk seenaknya memilih di antara agamaagama. Tetapi bukan itu maksud pengakuan terhadap kebebasan beragama. Agama tidak bisa dipilih sebagaimana halnya orang memilih keanggotaan dalam partai politik. Manusia berdosa besar apabila ada yang diyakini sebagai kebenaran Ilahi dan tidak diikutinya. Justru karena itu kebebasan setiap orang untuk beragama menurut apa yang diyakininya harus diakui.

Yang diakui dalam prinsip kebebasan beragama hanyalah sikap seseorang atau sekelompok orang terhadap hal yang bersifat Adiduniawi yang tidak boleh dicampuri manusia lain dan terutama tidak menjadi urusan negara. Sebaliknya , negara wajib menjamin bahwa setiap orang / golongan dapat beragama sesuai dengan apa yang mereka yakini.
Implikasi dari prinsip kebebasan beragama lainnya ialah prinsip non diskriminasi. Karena setiap orang wajib diizinkan beragama menurut apa yang diyakininya. Negara dalam perlakuan terhadap warga-warganya tidak boleh membeda-bedakannya menurut agama mereka masingmasing. Semua hak warga baik yang pasif maupun aktif harus dijamin bagi semua warga negara dengan tidak membedakan agama mereka.

2. Dari Toleransi ke Sikap Saling Menghormati

Meskipun toleransi adalah sikap yang sangat mendasar dan penting, toleransi masih terbatas jangkauannya. Bersikap toleran bukan berarti meniadakan, tidak memerangi, tidak memusuhi. Toleransi tidak lebih berarti sikap menahan diri, membiarkan, berbesar hati. Toleransi belum berarti suatu sikap positif.

Agar hubungan antar agama menjadi positif, toleransi harus harus dikembangkan menjadi sikap saling menghormati. Saling menghormati berarti mengakui hak orang dan golongan lainnya mengikuti 
agamanya. Kemampuan untuk hanya dapat mewujudkan menghormati sikap orang lain berarti solidaritasnya dengan menyerang dan pula suatu sikap arif dalam melihat menjelek-jelekkan agama atau pengembangan suatu budaya hati. keyakinan lain, iman umat itu Budaya hati itu, termasuk sebenarnya masih rapuh. kemampuan hati untuk bersikap Kemampuan untuk menghormati hormat terhadap keyakinan orang keyakinan orang dan golongan lain lain, terhadap apa yang dianggapnya justru merupakan tanda kemantapan suci, terhadap cara orang dan dalam iman kepercayaannya sendiri. golongan lainnya mengungkapkan keyakinan mereka, adalah kemampuan untuk menghormati apa yang suci, luhur, Ilahi bagi hati orang lain terlepas dari apa keyakinan kita sendiri. Sikap itu akan kelihatan dalam cara berbicara, dan menulis tentang agama lain, juga kalau tidak ada orang dari agama lain itu hadir. Orang yang mempunyai budaya hati ini tidak pernah akan bicara, merendahkan pihak lain, sinis, mengejek tentang apa yang diyakini orang lain. Dan meskipun tidak menerima kepercayaan agama lain, ia menghormati anggapan mereka tentang kepercayaan mereka.

Sikap saling menghormati akan sangat mendukung hubungan baik antara agama-agama, dan bukan hanya itu, selama umat beragama

\section{Dari Saling menghormati ke \\ Saling Menghargai \\ Apabila hubungan saling} menghormati antara agama-agama dapat dibangun, hanya tinggal langkah kecil saja menuju sikap yang seakan-akan mengunci hubungan itu yakni kemampuan untuk saling menghargai.

\section{Menghormati}

berarti mengakui secara positif keberadaan pihak lain, termasuk keyakinannya. Menghargai, melebihi sikap hormat, berarti melihat hal-hal positif dalam agama dan kepercayaan orang lain. Itu berarti mampu belajar satu sama lainnya. Tentu saja ini tidak masuk dalam relatiivisme agama. Orang Katolik bila melihat banyak hal positif dalam Islam, juga pada agama Budha, yang diperlukan tidak hanya 
Komunike, Volume XII, No. 1 Juni 2020

sikap hormat tapi juga sikap kagum yang seharusnya membantu dia memperdalam, kadang-kadang untuk meluruskan kembali keyakinan Katoliknya sendiri.

Sikap salng menghormati dan menghargai, lalu memungkinkan orang dari agama-agama berbeda bersama-sama berjuang demi pembangunan yang sesuai dengan martabat yang diterima manusia dari Tuhan. Solidaritas dengan orangorang kecil, miskin, lemah, dan menderita, keadilan sosial, pembebasan dari penindasan dan pemerkosaan dan perwujudan kehidupan yang lebih demokratis adalah hal-hal yang dapat dilakukan oleh agama-agama secara bahu membahu. Inilah upaya untuk mewujudkan kehidupan masyarakat dengan suatu cara yang lebih positif, lebih sesuai dengan kehendak Sang Pencipta.

4. Toleransi Bukan Relativisme Agama Sikap hormat dan penghargaan terhadap agama dan golongan lain tidak berarti bahwa agama dan keyakinan itu harus dianggap benar. Menghormati kepercayaan seseorang tidak berarti mempunyai pandangan dunia yang sama dengan dia. Bahkan mungkin bisa menganggap kepercayaan orang lain keliru atau kurang benar, kurang lengkap, kurang tepat. Hakekat sikap hormat terhadap agama lain adalah bahwa ada pengakuan terhadap hak eksistensi keyakinan dan kepercayaan yang lain itu. Seseorang tidak harus mengakui isi kepercayaan itu. Tetapi menerima baik bahwa seseorang atau suatu umat dapat hidup sesuai dengan apa yang menjadi keyakinan mereka.

Sikap hormat itu didasarkan pada pengakuan mendalam terhadap kesucian panggilan Tuhan dalam hati orang. Seseorang menerima dengan baik bahwa orang dan golongan dapat mengikuti dengan setia apa yang mereka yakini sebagai kebenaran meskipun tidak mengakui dan meyakini kebenaran dan keyakinan mereka.

Maka menghormati agama lain tidak ada hubungannya dengan ucapan "semua agama sama saja". Ucapan itu bertentangan dengan keyakinan sendiri maupun dengan 
sikap hormat terhadap agama lain. Jadi toleransi dan hormat terhadap agama lain jauh dari relativisme agama. Relativisme agama, yang banyak terdapat di Barat, tapi hanya di antara mereka yang betul-betul tidak lagi beragama, berpendapat bahwa agama manapun yang diikuti orang sama saja, karena semua keyakinan sama saja. Ini adalah pandangan yang salah karena bertentangan dengan klaim kebenaran dari semua agama.

Disamping konsep toleransi sebagaimana yang diungkapkan di atas, sikap lain yang juga perlu untuk ditumbuhkan untuk dapat menerima pluralisme agama adalah adanya upaya mencari tahu keyakinan lain di luar keyakinan sendiri agar bisa mendapat pemahaman yang berimbang daripada sekedar menyerap isu-isu yang kurang bisa dipertanggungjawabkan. Cara ini terlihat dalam dialog antar umat beragamayang mampu berfungsi

\footnotetext{
${ }^{31}$ Saifudin Asrori, "Modal Sosial dan Dialog Antar Agama: Strategi Peningkatan Harmoni Antar Umat Beragama di Indonesia." Jurnal PENAMAS Volume 32, no.1, 2019, hlm.385-408
}

sebagai wahana integrasi social. ${ }^{31} \mathrm{Hal}$ ini antara lain dapat diwujudkan dalam bentuk dialog antar iman sebagaimana dicontohkan oleh Hans Kung dan Sayyed Hossein Nasr ${ }^{32}$, atau konsep yang ditawarkan oleh John S. Dunne yang disebutnya dengan "passing over" atau melintas, yaitu melintas dari satu budaya ke budaya yang lain, dari satu cara hidup ke cara hidup yang lain, dari satu agama kepada agama yang lain. Tetapi Dunne menambahkan bahwa proses melintas harus diikuti proses kembali (coming back), tetapi kembali dengan wawasan baru kepada budaya sendiri, cara hidup sendiri, dan agama sendiri. Pengembaraan religius dan spiritual ini akan memperkaya pengalaman dan menambah wawasan-wawasan baru kepada pelakunya. Kautsar Azhari Noer mencatat sejumlah tokoh Islam yang melakukan praktek "passing over" dan “coming back" seperti Dara Shikoh, Inayat Khan, dan Seyyed

\footnotetext{
${ }^{32}$ Hans Kung dan Seyyed Hossein Nasr, "Mencari Model Dialog Kristen Islam". Jurnal Pemikiran Islam Paramadina Volume I, no.1, 1998. hlm. 9-33
} 
Komunike, Volume XII, No. 1 Juni 2020

Hossein Nasr. Mereka berangkat dari Islam melintas ke Hinduisme, Buddhisme, Kristen, Yahudi, Konfusianisme, Taoisme, untuk akhirnya kembali ke dalam Islam. ${ }^{33}$

Konsep-konsep di atas, baik itu dialog antar agama maupun konsep "passing over" dan "coming back" bukanlah konsep yang mudah untuk diaplikasikan terlebih kepada masyarakat umum di Indonesia. Namun melalui dakwah Islamiyah yang memiliki pendekatan yang beragam, konsep-konsep di atas meskipun dalam skala yang kecil dapat diupayakan sebagai sebuah bentuk jalan tengah dari perdebatan atas masalah pluralisme agar tidak senantiasa menjadi kontroversi yang berkepanjangan. Dakwah juga bisa menjadi medium pengembangan wawasan multikultural yang melibatkan semua pihak dalam masyarakat. Upaya pelibatan semua elemen masyarakat perlu untuk

${ }^{33}$ Komaruddin Hidayat, Ahmad Gaus AF, (editor), Passing Over, Melintasi Batas Agama (Jakarta: Gramedia Pustaka Utama dan Yayasan Wakaf Paramadina, 1999) hlm. xiv dilakuakn agar semua pihak punya wawasan yang seimbang tentang realitas multikultural dalam masyarakat. Dengan demikian selain dapat meningkatkan komunikasi kelompok-kelompok yang berbeda, juga sekaligus berguna sebagai upaya peningkatan pengelolaan kemajemukan masyarakat. $^{34} \mathrm{Hal}$ ini dimungkinkan karena dakwah Islamiyah sudah menjadi sebuah kekuatan masif dalam kehidupan masyarakat Islam yang bisa masuk ke dalam seluruh aspek kehidupan masyarakat Islam. Semua upaya ini dilakukan untuk menjadikan pluralisme diterima sebagai sebuah realitas yang wajar dan bisa dikonstruksi sebagai kekuatan sosial untuk kemaslahatan bersama.

\section{KESIMPULAN}

Pluralisme secara umum dimaknai sebagai keragaman dalam berbagai aspek kehidupan. Dalam kaitannya dengan agama, maka

${ }^{34}$ Zainuddin Daulay, "Implementasi Kebijakan Pengembangan Wawasan Multikultural: Solusi Mengatasi Persoalan Pluralitas Kehidupan Masyarakat dan Bangsa. Harmoni, Jurnal Multikultural dan Multireligius Volume IV, 2005. 123-134. 
pluralisme adalah keragaman keyakinan agama terutama dalam aspek syariatnya, sementara dalam aspek esensialnya ada yang berpandangan bahwa hal itu hanya satu karena bersumber dari yang satu yaitu Tuhan. Pada aspek inilah terjadi kontroversi di kalangan umat Islam khususnya di Indonesia dengan argumentasinya masing-masing.

Dalam sejarah dakwah Nabi Muhammad saw, khususnya dalam periode Madinah terlihat bagaimana dakwah menghadapi realitas pluralitas keyakinan dan memperlakukan realitas pluralisme tersebut sebagai kekuatan sosial dengan menempatkan semua keyakinan sama di bawah Piagam Madinah dengan hak dan kewajiban yang sama. Fakta ini memperlihatkan bahwa dalam Islam perbedaan keyakinan bukanlah halangan untuk mengelola kehidupan sosial bersamasama sebagai satu bentuk penerimaan terhadap pluralisme agama.

Beberapa sikap yang harus dikembangkan untuk dapat menerima realitas pluralisme agama dalam kehidupan sehari-hari antara lain melalui dialog antar agama, melakukan aktivitas "passing over" dan "coming back", atau melakukan upaya peningkatan wawasan multikulturalisme kepada seluruh elemen masyarakat. Semua hal ini bisa dilakukan melalui medium dakwah Islamiyah yang dengan beragam pendekatannya, telah menjadi gerakan sosial keagamaan Islam yang masif dan mampu menjangkau seluruh aspek kehidupan masyarakat Islam.

\section{DAFTAR PUSTAKA}

Adib, Muhammad. Qomari, Nur. 2018. "Arus Baru Politik Islam: Pluralisme, Kontestasi, dan Demokra-tisasi, Maqashid, Jurnal Hukum Islam 1, no. 2: 18-33

Amin, M. Masykur. 1997. Dakwah Islam dan Pesan Moral. Yogyakarta: Al-Amin Press.

Arnold, Thomas Walker. 1981. Sejarah Da'wah Islam. Jakarta: Widjaya.

Asrori, Saifudin. 2019. "Modal Sosial dan Dialog Antar Agama: Strategi Peningkatan Harmoni Antar Umat Beragama di Indonesia." Jurnal PENAMAS 32, no.1:385-408

Dananjaja, James, Metode Penelitian Kepustakaan, Jurnal 
Antropologi Indonesia Nomor 52, 1997, 83

Daulay, Zainuddin. 2005. "Implementasi Kebijakan Pengembangan Wawasan Multikultural: Solusi Mengatasi Persoalan Pluralitas Kehidupan Masyarakat dan Bangsa. Harmoni, Jurnal Multikultural dan Multireligius IV, 123-134.

Departemen Pendidikan dan Kebudayaan. 2002. Kamus Besar Bahasa Indonesia. Jakarta: PN Balai Pustaka.

Al-Dimasyqi, Taqyuddin Abu AlAbbas Ahmad bin Abd AlHalim bin Abd Al-Salam bin Abdullah bin Abi Al-Qasim bin Muhammad Ibn Taymiyyah Al-Harrani AlHanbali. 1408-1987. AlFatawa Al-Kubra Li-Ibn Taymiyyah. t.tp: Dar AlKutub Al-Ilmiyyah.

Echols, John M. Shadiliy, Hassan. 1996. Kamus Inggris Indonesia. Jakarta: PT Gramedia Pustaka Utama.

Haikal, Muhammad Husain. 1989. Sejarah Hidup Muhammad. Jakarta: Litera Antar Nusa.

Hidayat, Komaruddin. Gaus AF, Ahmad. (editor). 1999. Passing Over, Melintasi Batas Agama. Jakarta: Gramedia Pustaka Utama dan Yayasan Wakaf Paramadina.
Hijrah S. 2019. MUI, Kontroversi Fatwa MUI, dan Buku Himpunan Fatwa MUI, dalam http://www.erlangga.co.id/ag ama/7066-mui-kontroversifatwa-mui-dan-buku$\underline{\text { himpunan-fatwa-mui.html }}$

Hikmawan, M. Dian. 2017. "Pluralisme Demokrasi Politik di Indonesia". Journal of Governance 2, no. 2: $223-247$

Jauhar, Najid. 2007. "Islam, Demokrasi, dan HAM, Sebuah Benturan Filosofis dan Teologis". Jurnal Ilmu Sosial dan Ilmu Politik 11, no. 1: $31-61$

Kung, Hans. Nasr, Seyyed Hossein. 1998. "Mencari Model Dialog Kristen Islam". Jurnal Pemikiran Islam Paramadina I, no.1: 9-33

Latif, Hamdiah A. 2011. "Mengkritisi Jaringan Islam Liberal (JIL): Antara Spirit Revivalisme, Liberalisme, dan Bahaya Sekularisme. Jurnal Ilmiah ISLAM FUTURA 10, no.2: 50-64

Munawwir, Ahmad Warson. 1997. Kamus Al-Munawwir Arab Indonesia Terlengkap. Surabaya: Pustaka Progressif.

Nasution, Harun. 1985. Islam Ditinjau Dari Berbagai Aspeknya. Jakarta: UI Press. "Pluralisme". 2019. Wikipedia Indonesia Ensiklopedia Bebas. 
Komunike, Volume XII, No. 1 Juni 2020

http://id.wikipedia.org/wiki/ Pluralisme

Rahmat, Jalaluddin. 1998. Islam Aktual. Bandung: Mizan.

Rachman, Budhy Munawar. 2001. Islam Pluralis. Jakarta: Paramadina.

Rohmanu, Abid. 2009. "Pluralisme, Demokrasi dan Keadilan Sosial Dalam Konsepsi Fiqih Humanistik Abou El-Fadl” ISLAMICA 4, no.1: 17-34

Shihab, HM Quraish. 1997. Membumikan Al-Qur'an. Bandung: Mizan.

Suma, Muhammad Amin. 2001. Pluralisme Agama Menurut Al-Qur'an, Telaah Aqidah dan Syari'ah. Jakarta: Pustaka Firdaus.

Sumardi, Dedy. 2016. "Islam, Pluralisme Hukum dan Refleksi Masyakat Homogen". Asy-Syir'ah, Jurnal Suari'ah dan Hukum 50, no. 2: 481-504
Suseno, Franz Magnis. 1995. Pluralisme Keagamaan: Sebuah Tanggung Jawab Bersama, dalam Muhammad Wahyuni Nafis dkk (editor), Kontekstualisasi Ajaran Islam. Jakarta: IPHI dan Yayasan Wakaf Paramadina.

Taha, Anis Malik. 2005. Tren Pluralisme Agama, Tinjauan Kritis. Jakarta: Gema Insani Press.

Widodo, Rusman. 2014. Editorial Jurnal HAM Komnas HAM. 11: v-xvi

Zarkasyi, Hamid Fahmy. 2011. "Liberalisasi Pemikiran Islam: Gerakan Bersama Missionaris, Orientalis, dan Kolonialis." Jurnal TSAQAFAH 5, no.1: 1-28

Zed, Mestika, Metode Penelitian Kepustakaan (Jakarta: Yayasan Obor Indonesia, 2008. 